\title{
MONTHLY
}

JAMES E. CASKEY, JR., Editor

\section{EXPLORATORY FIRECLIMATE SURVEYS ON PRESCRIBED BURNS}

\author{
MARK J. SCHROEDER \\ U.S. Weather Bureau, Berkeley, Calif. \\ and \\ CLIVE M. COUNTRYMAN \\ Pacific Southwest Forest and Range Experiment Station, Berkeley, Calit. \\ [Manuscript received February 15, 1960; revised April 11, 1960]
}

\begin{abstract}
In the summer of 1957 , short-term weather surveys were made in four prescribed burn areas in the central Sierra Nevada foothills and in the central Coast Range in California The local fireclimate patterns were studied, a fire-weather forecast was adapted to the burn area for each fire, and attempts were made to note the effects of the fires on the fireclimate patterns. This paper describes the survey techniques used, gives an example of a forecast, and discusses some of the survey results. The latter include an increase in wind speed blowing out of the lee side of the fire, effects of the broadscale weather on the local patterns, down-canyon afternoon winds in east-facing canyons, and temperature observations and topographic effects on the lee side of a ridge.
\end{abstract}

\section{INTRODUCTION}

In California more than 100,000 acres of brushland are burned each year under prescribed conditions in order to improve the range land, reduce the fire hazard, or prepare the land for tree planting. The burns offer an excellent opportunity to study the local weather and to note the effects of the fire on it. At the same time fireclimate surveys offer many opportunities for improving the safety and effectiveness of prescribed burns.

A preliminary survey [1] on a prescribed burn on the Lassen National Forest in 1956 convinced us that shortterm surveys were feasible in the summertime in the interior of California. Accordingly for the 1957 summer season we selected four prescribed burn areas for study. Two of these were in the western foothills of the central Sierra Nevada and two were in the eastern part of the central Coast Range. In each case an area in rather simple topography was selected. fold:

The objectives of these short-term surveys were three-

(1) To determine the local fireclimate patterns and, when possible, note how they are affected by changes in the broadscale weather pattern.

(2) To provide a detailed fire-weather forecast using information obtained on the survey and a general forecast from the fire-weather forecaster.

(3) To note the effects of the fire on the fireclimate pattern.

This paper describes the survey techniques used, gives an example of a forecast, and presents the principal results of each of the four surveys. More detailed information is available in individual reports for each survey $[2,3,4,5]$.

\section{SURVEY TECHNIQUES}

The survey techniques used were, in general, the same on all four prescribed burns. Equipment was set up and observations started 3 to 8 days before the scheduled date of the burn. Both recording stations and manual instruments were included in the equipment.

Recording stations used Esterline-Angus milliammeter recorders connected to resistance-type wind vanes for wind direction. An auxiliary impulse recording pen was con- 


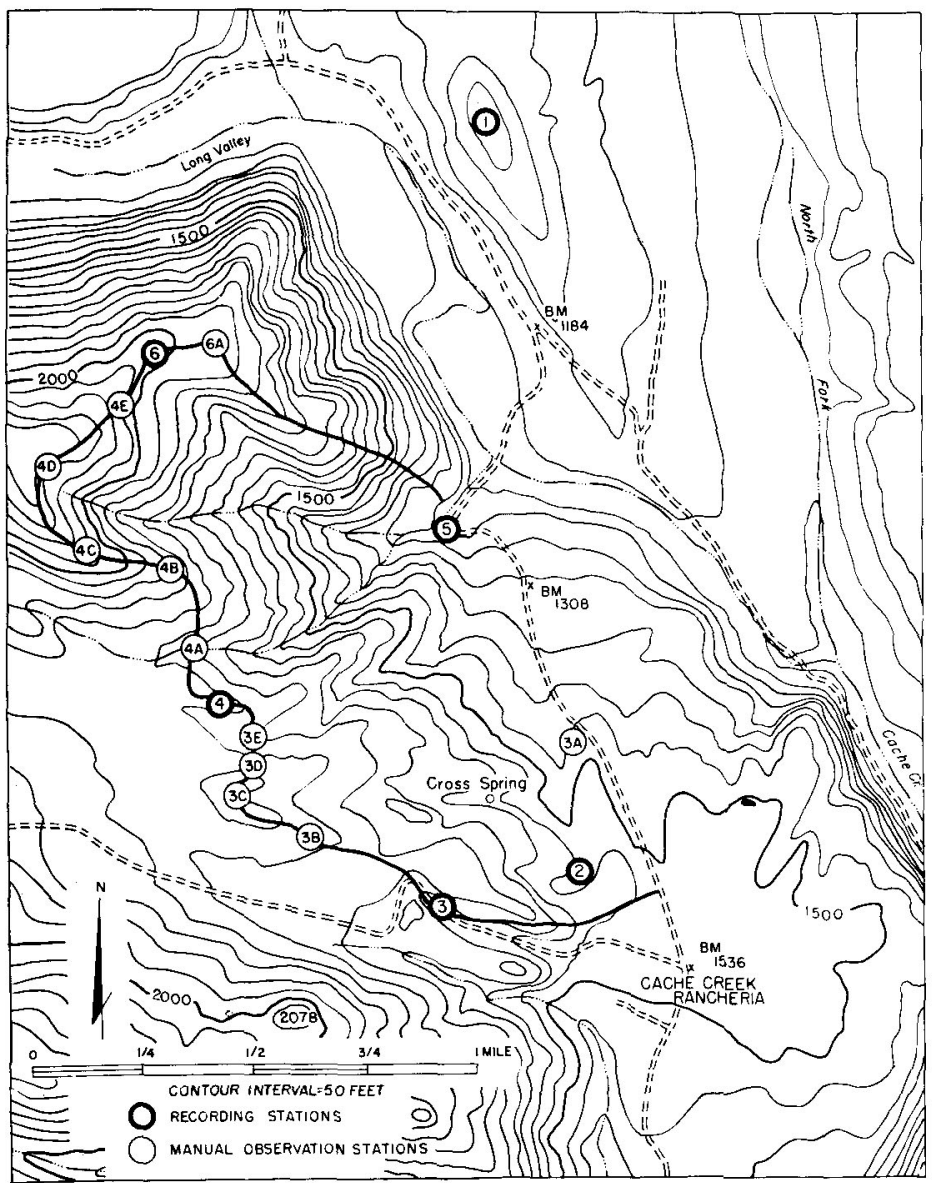

Figure 1. - Station locations on Prescribed Burn Survey 3-57, the Ford Ranch in Lake County.

nected to Robinson anemometers for wind speed. Anemometers and wind vanes were placed on tripods and exposed about 10 feet above the ground. Five of these recording units were used on each of the first two surveys and six on the last two. Three 30-hour portable hygrothermographs were used for recording temperature and relative humidity; these were placed in small instrument shelters designed and built for this purpose.

Instruments used for manual observations were Dwyer wind meters and standard wet- and dry-bulb sling psychrometers.

Sites for the recording stations were selected to give the best possible picture of the local weather pattern. Usually some stations were placed on ridges and in saddles on the periphery of the burn area, and others in the bottoms of the main drainage and smaller draws (fig. 1). One well exposed station site was selected far enough from the burn area so that the fire was not expected to influence its readings. This station could then be used for comparison while analyzing the records for fire effects on the local weather pattern. As much as possible, we selected well-exposed sites for the recording stations (fig. 2), but in the bottoms of draws such exposures could not always be obtained.

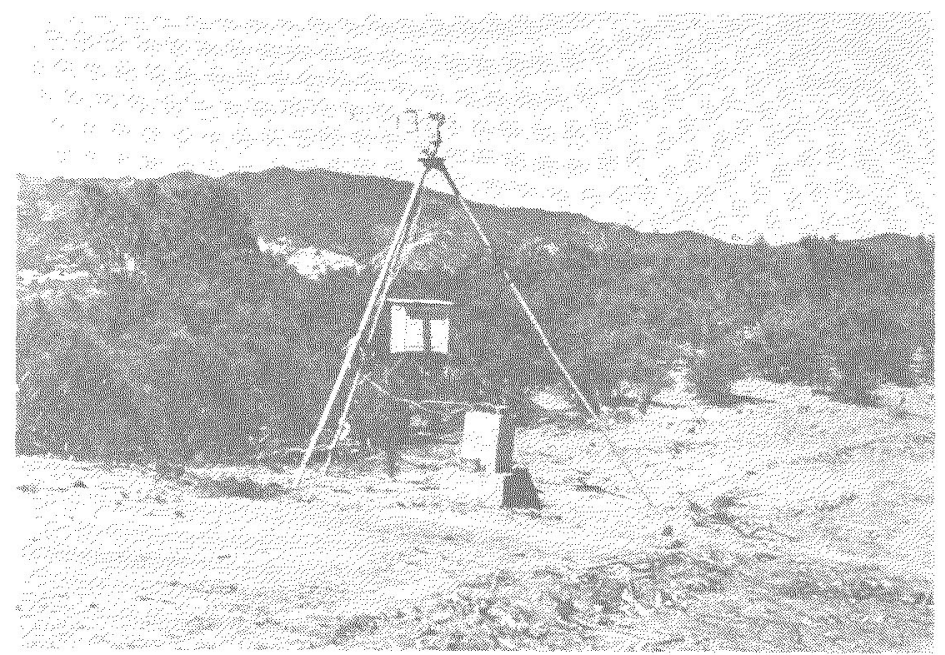

Figure 2:-A typical recording station.

Manual observations were made at a number of selected sites to provide intermittent samples of wind direction and speed, temperature, and relative humidity. By supplementing the recorders, these readings helped round out a picture of the local weather patterns.

All of the recording stations that were considered to be safe from the fire were left in operation on the day of the burn. In addition, we made frequent manual weather observations and took notes and pictures of the fire to document its behavior.

During the course of each survey a preliminary tabulation and an analysis of recorder records and manual observations were made. The purpose was to determine the daily march of temperature and relative humidity, and the patterns of the daytime and nighttime winds, and the times and character of changes. We obtained by telephone from the Fire-Weather Forecast Center descriptions of the general weather patterns. We were then able to associate significant changes in local weather to changes in the synoptic weather patterns.

After the field survey was completed, the data were analyzed in considerable detail. Surface and upper-air weather maps for the period were studied to attempt to explain changes in the local weather observed on the survey. Notes and pictures of the fire were studied with the weather records in a search for effects of fire on the local weather patterns.

\section{EXAMPLE OF FORECAST}

On the day before the scheduled day of each prescribed burn we telephoned the Weather Bureau Fire-Weather Center for a general forecast for the fire area. Then, using the knowledge of the local weather patterns and their relationship to changes in the synoptic pattern we had obtained from our preliminary analysis of the survey data, we were able to provide a detailed forecast for the burn area. The fire-weather center was contacted again 
on the forenoon of the day of the burn to assure that no new conditions would render the forecast obsolete.

The following forecast is the one made for a burn on the Ford Ranch in the central Coast Range and is typical of the forecasts provided:

Fire-Weather Forecast for Prescribed Burn 3-5\%, August 19, 1957

The weather and wind patterns observed during the past several days will continue today with very little change. The maximum temperatures will be 93-95 and minimum relative humidities 14-16 percent, occurring about 1530 PST. The temperatures will rise rapidly and humidities fall rapidly during the forenoon until around 1000 PST and then change more slowly. The temperatures at 1200 PST will be around $90^{\circ}$ and the humidity around 20 percent. Minimum temperatures tomorrow morning 50-65 and maximum humidity 55-65 occurring about 0600 PsT. The time of the wind shift from down-canyon to up-canyon tomorrow morning will be around 0600 PST.

Winds during the forenoon will be blowing up the canyon and draws, NE, E, or SE depending upon the orientation, at speeds of 2-4 m.p.h. Between 1000 and 1200 PsT the influence of the prevalling W to SW gradient wind will become stronger and result in a shift in the local winds to mostly down-canyon. Directions will vary from SW, WNW-again depending upon the orientation. Winds will become stronger after the shift. Speeds will be 8-14 m.p.h. at higher elevations on the west side of the area with gusts as high as 20 m.p.h. On the east side of ridges and near the top of steep slopes roll eddies will form. Conflicting wind currents along Cache Creek Valley and Long Valley could create erratic wind patterns in the area east of Station 5.

This general wind pattern will continue during the afternoon and even during the evening hours except that at the lower elevations speeds will drop off quickly after sunset. At the higher elevations speeds will remain 6-12 m.p.h. until near midnight and then decrease to $2-4$ m.p.h.

Slight cooling aloft, coupled with maximum temperatures in the mid 90's will result in a relatively unstable layer to at least 10,000 feet. Thus a rather tall convective column may be expected.

A map showing the expected wind pattern in the burn area for the scheduled time of the burn was provided along with the written forecast.

Actual weather conditions observed on the day of the burn were very close to predicted values. The up-slope thermal winds continued until about 1000 PsT, when the wind shifted to westerly and picked up rapidly in speed to approximately that predicted.

\section{SURVEY RESULTS}

\section{PRESCRIBED BURN SURVEY 1-57}

This burn area was in the lower foothills of the west slope of the Sierra Nevada about 24 miles northeast of Fresno, Calif. Slopes were mostly moderate and the whole burn area had a westerly aspect. Because of limited instrumentation, survey efforts were concentrated on the eastern edge of the area where the hottest fire activity was most likely.

The most important finding in this survey was that of a wind blowing with increased speed out of the leeward side of the fire (fig. 3A). This is contrary to the wind action commonly believed to occur. Previously, most workers thought that indraft into the fire area usually reduces the wind speed and frequently reverses the direction of the prevailing wind on the lee side of the fire. However, before these surveys, little quantitative information was available about wind action as close to the fire as these observations.

The effect is apparent in the record at two Stations, $A$ and B. Perimeter firing first brought fire into the vicinity of Station A about 1148 PST. At this time the wind at Station A was southwest (fig. 4). As the fire built up heat in the heavy fuels in a ravine below Station A, the wind shifted from southwest to west (directly up-canyon and directly from the fire toward Station A) and picked up in speed. Station B, which was not being affected by the fire at this time, showed no such changes. A short time later the fire had again reached another heavy fuel concentration. Again the wind at $A$ shifted to westerly and increased sharply in speed. A similar change in wind direction was noted later at Station B when the fire burned briskly beneath it, but the increase in speed was not evident.

At the time that we wrote our report [2] on this survey we suggested that this wind increase was caused by fire burning in a topographically confined area, so that the heated air created by the fire accentuated the normal up-canyon wind. However, since then another case [6] has come to our attention where a similar wind increase was observed in a less confined area while down-valley drainage winds were occurring (fig. $3 \mathrm{~B}$ ). It was an experiment in which a crib of logs was burned in a large east-west valley. Surface weather observations and double theodolite pibals were taken at several distances east and west of the fire. On the leeward side of the fire a threefold increase in wind speed was measured in the down-canyon direction (out of the fire). This increase was definitely fire-induced since such wind speeds were not measured either on the windward side of the fire or aloft. The explanation given is that the increase was caused by expansion of air resulting from the intense fire. An indraft into the fire on the leeward side was observed only after the down-valley drainage winds decreased and the fire flames subsided.

\section{PRESCRIBED BURN SURVEY 2-57}

This burn area also was in the lower Sierra Nevada foothills about 15 miles southwest of Sonora, Calif. Most of the area was on east-facing slopes on the west side of Don Pedro reservoir. The ridge on the western edge of the area was oriented approximately at right angles to the prevailing wind. Where such is the case, experience has shown that erratic fire behavior frequently occurs on the lee side.

During the course of the survey the remnants of a cold front passed through the area and provided an opportunity to see that such a change in the synoptic pattern may affect the local weather. A rather deep layer of marine 


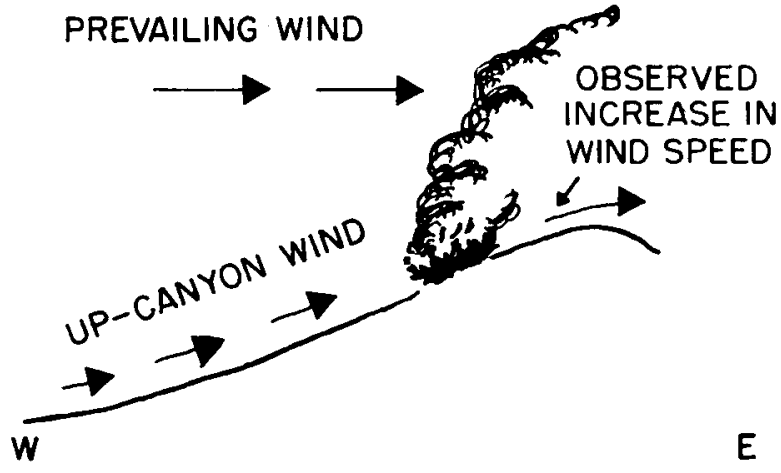

A

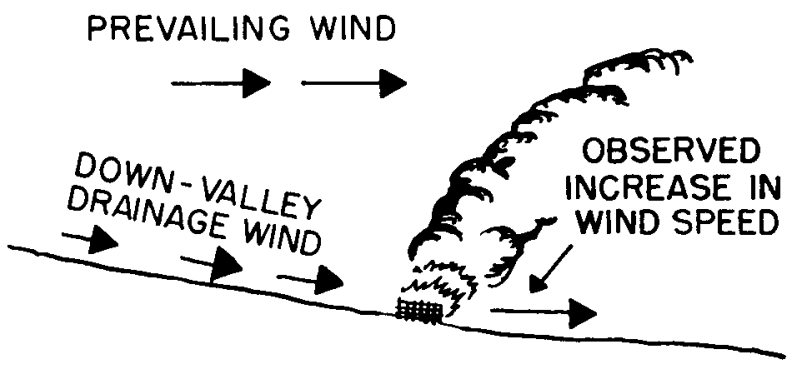

w

B

FiguRe 3.--Regions where increased wind speeds were observed (A) on Prescribed Burn 1-57 and (B) on U.S. Army mass fire control test.

16
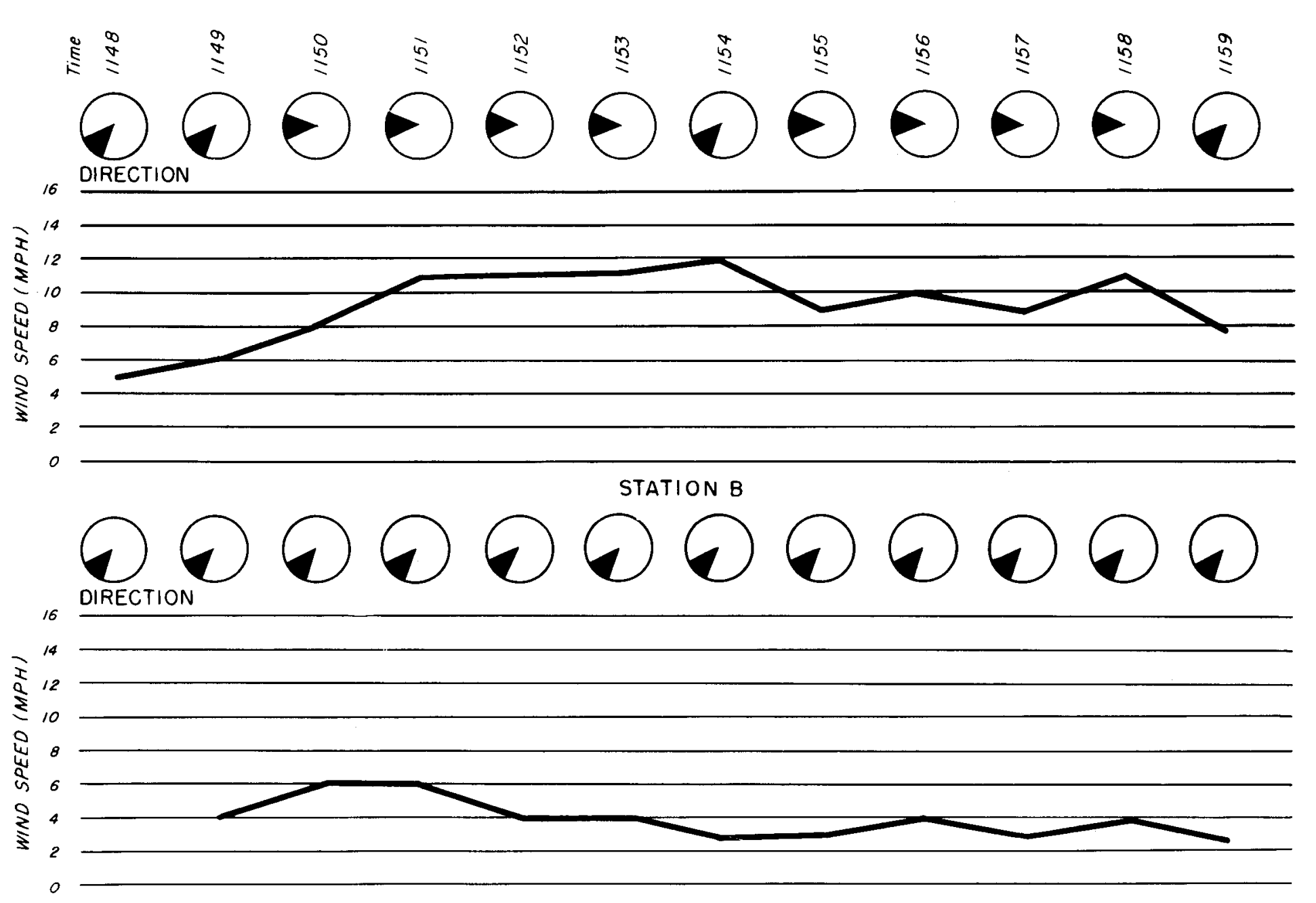

Figure 4.-Wind speed and directions at Stations A and B on Prescribed Burn Survey 1-57, 1148 to 1159 PsT. North is at the top of the circles.

air moved into the area with the frontal passage, as was evident from the lower temperatures and higher humidities observed at all stations.

The wind patterns were also affected by the synoptic change. Near the top of the ridge the wind direction on most days was southwesterly during the afternoon. On the 2 days when the penetration of marine air was strongest, the wind was westerly throughout the daytime hours. On these 2 days westerly or northwesterly winds were observed in all but the most sheltered areas and the 


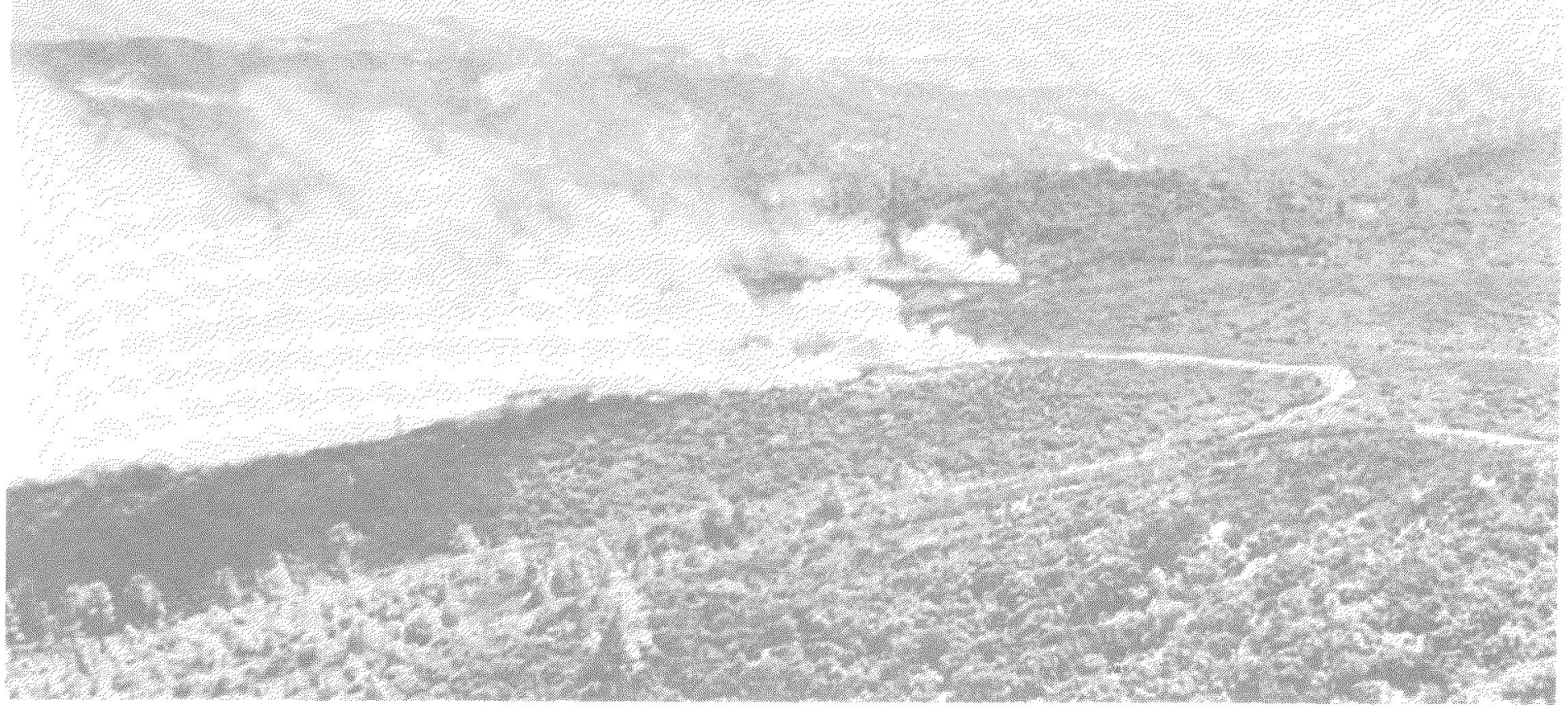

Frgure 5.-Prescribed Burn 3-57 at 1134 pst. Note down-slope winds here and in figure 6.

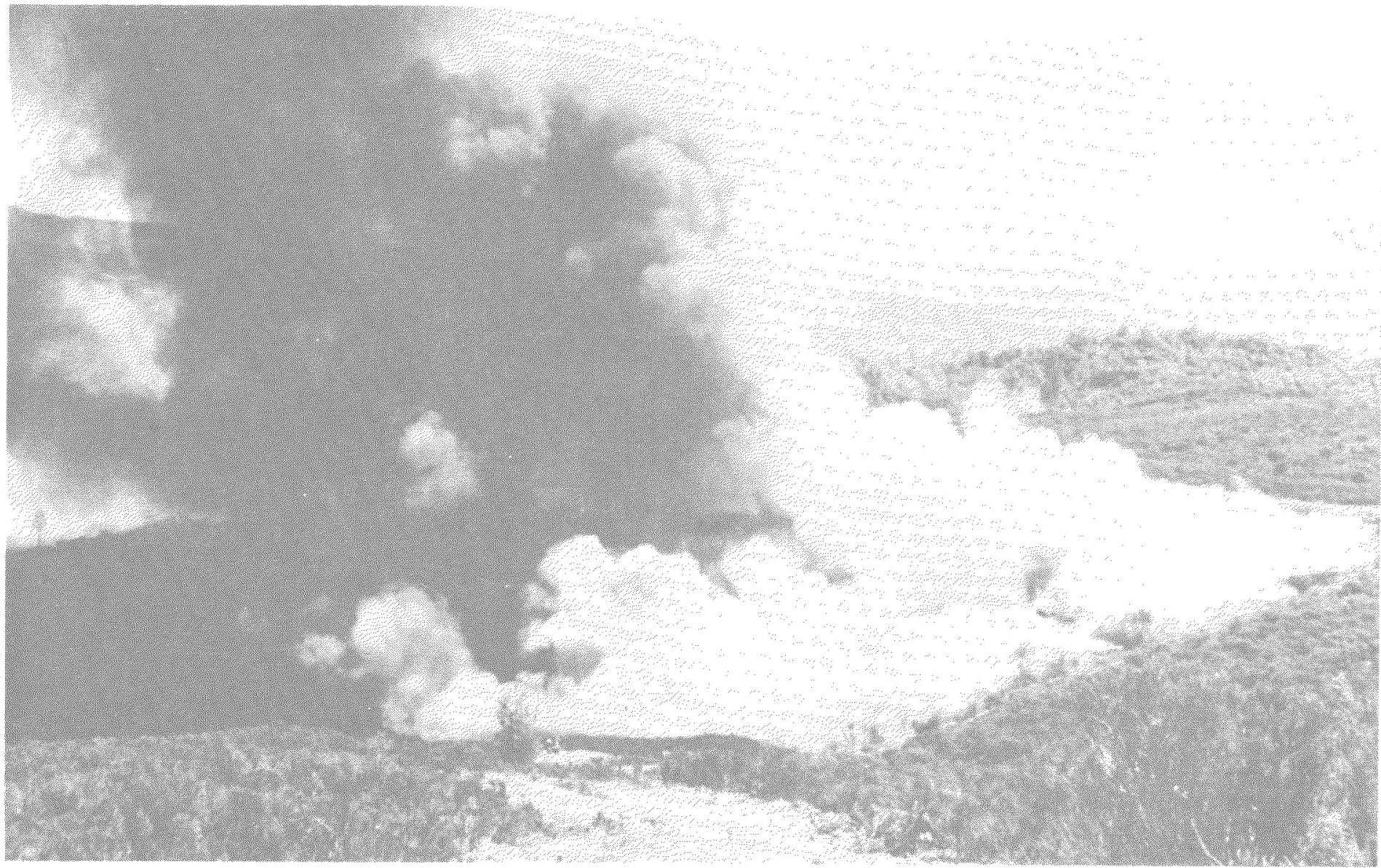

FigURE 6.-Prescribed Burn 3-57 at 1212 pST. 
local thermal wind patterns were obscured. After that the local circulations were again dominant.

Another finding was that in east-facing canyons of the Sierra foothills, the up-canyon thermal wind which sets in early in the forenoon can be replaced during the day by a down-canyon wind. On several days just preceding the burn this change took place about 1000 PsT. It was indicated in the forecast for the day of the burn and did occur. These down-canyon afternoon winds were known to occur in various places in the coastal ranges of California but were not known to occur in the Sierra foothills.

A third item worthy of mention is the fact that a firewhirl, which developed in the fire, moved over and upset one of the recording stations. It developed on the lee side of a ridge, an area which is known to be a favored place for firewhirls [7]. In this case the whirl developed in the general area where the survey had shown indications of eddy circulations on previous days.

\section{PRESCRIBED BURN SURVEY 3-57}

The third burn area, also with an easterly aspect, was in the Coast Range, in Lake County about 150 miles north of San Francisco and about 60 miles from the Pacific Ocean. The area and station locations are shown in figure 1.

The most important result of this survey was the documentation of the occurrence of down-slope, downcanyon afternoon winds in an area having an easterly aspect. In the absence of a strong general pressure gradient, the classic pattern calls for up-slope, up-canyon thermal winds during the day and down-slope, downcanyon drainage winds at night. The local winds in this area during the course of the survey did not follow the classical pattern.

Shortly after sunrise each morning thermal up-slope, up-canyon winds developed as one would expect. These winds were quite light, averaging $2-4 \mathrm{~m}$.p.h., and continued through most of the forenoon. Then between 1100 and 1200 PST the winds switched rather quickly to a westerly direction and increased in speed. Soon the westerly flow was well established and down-slope, downcanyon winds covered the burn area; speeds of 15-18 m.p.h. frequently occurred in middle and late afternoon. After sundown wind speeds dropped off gradually until more normal down-slope and down-canyon drainage winds predominated.

The down-slope winds are evident from the smoke movement in figures 5 and 6 . These pictures were taken looking about south-southwest from the vicinity of station 6 toward stations 3 and 4 (fig. 1). The winds appear to be from about west-southwest. The down-slope winds were of sufficient force to exert almost complete control of the behavior of the fire. Burning embers were carried across Cache Creek. There they produced numerous spot fires, which coalesced into a wide fire front that ran rapidly to the east.

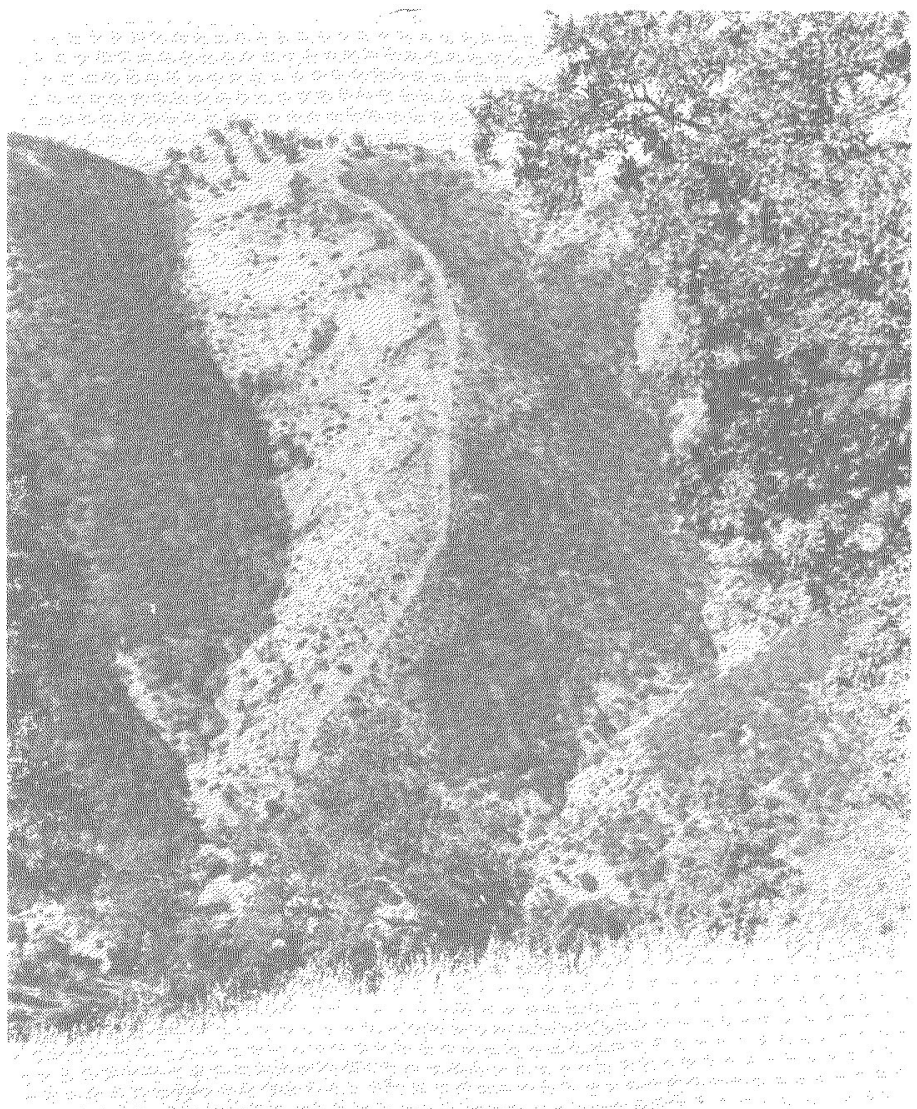

Figure 7.-Transect T-1 at northern end of burn, Prescribed Burn Survey 4-57.

\section{PRESCRIBED BURN SURVEY 4-57}

The fourth burn area was in the Vaca Mountains in the Coast Range, about 70 miles west of Sacramento, Calif. It was on the west side of a canyon running southsoutheastward and extended from the canyon bottom to the ridge top. Of easterly aspect, the area was characterized by several small, well-defined ravines leading into the main canyon (fig. 7). The ravines were separated by spur ridges sloping steeply down from the main ridge.

The most common daytime wind pattern during the survey period was one with a southerly, up-canyon wind in the main canyon, variable winds in the ravines leading into the main canyon and along the upper portion of the slope, and a prevailing southwest or west wind over the ridge tops. Here again down-slope winds were found in the daytime but usually for only short periods of time. This general pattern was not observed on the last two days of the survey when a northerly general wind flow produced northerly winds in the survey area both day and night.

Manual measurements taken along the spur ridge shown in figure 7 revealed interesting wind and temperature patterns. A transect made on the afternoon of September 5, 1957, is shown in figure 8 . On the lower two-thirds of the slope the wind direction was generally 


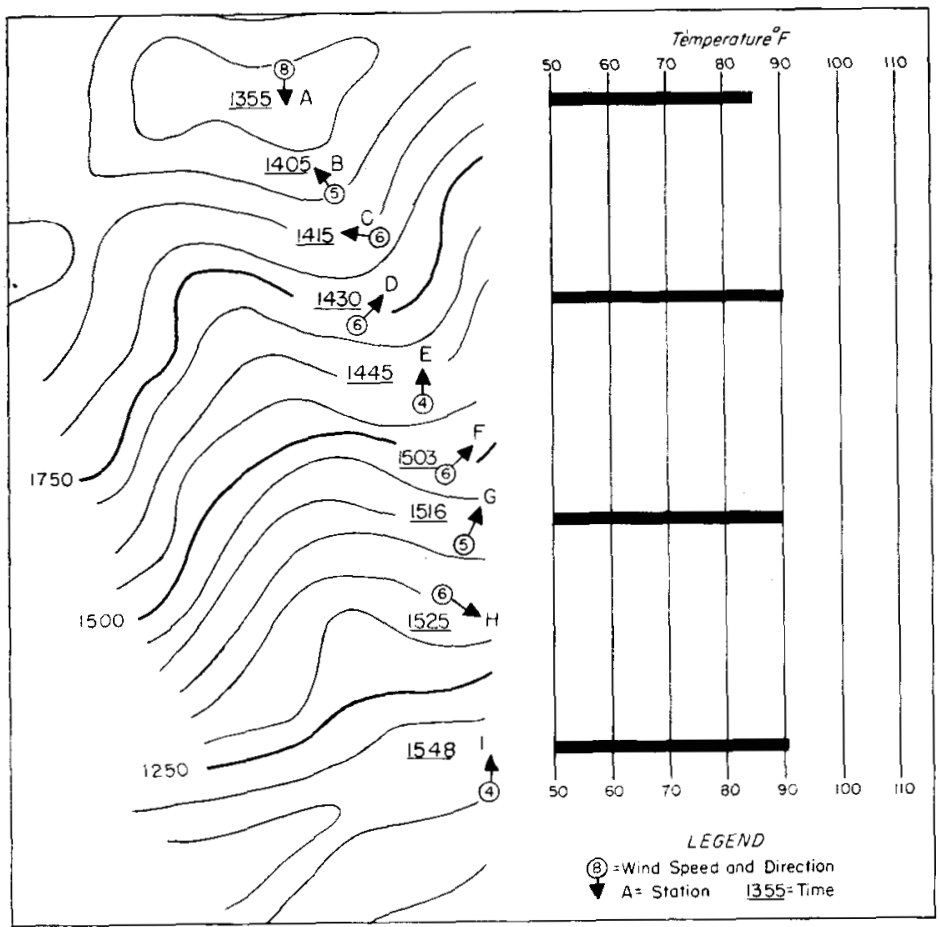

Figure 8.-Wind and temperature transect at T-1 (fig.7), September 5, 1957.

up-canyon or quartering up-slope. The prevailing west wind was evident at Station $A$ (the top of the chart is west). The opposing wind directions at Stations $\mathrm{A}$ and $B$ were apparent whenever a westerly wind was blowing across the ridge and would indicate the presence of a horizontal or roll eddy along the ridge on the lee side.

The temperature at Station $A$ at the top of the ridge during the warm part of the day was always lower than temperatures taken farther down in the canyon. Other transects where temperatures were taken at all stations revealed the interesting fact that the bulk of this temperature difference occurred in the first 50 to 150 feet down from the ridge top. The readings, of course, were not taken at the same time, but we made a number of such transects at different times during the day and in both directions and all showed similar readings. This strong instability coupled with the mechanically produced roll eddy makes the lee side of a ridge a very critical areaone where erratic fire behavior may be expected.

\section{CONCLUSIONS}

After these surveys we were satisfied that such shortterm operations can be used as an aid in producing detailed fire-weather forecasts for prescribed burns. In addition, they can reveal details of local wind, temperature, and humidity patterns not previously documented, and can point up areas wherein more research effort is needed. As a result of these surveys, we have started a project to study primarily the occurrence of down-canyon afternoon winds in an east-facing canyon in the Coast Range in southern California.

These surveys have also revealed that local wind patterns are extremely complex. They appear to be made up of several circulations of different size scales. First there is the slope wind, and very closely related to it is the circulation in ravines and small side canyons leading into larger canyons or valleys. This circulation can be modified by the circulation in the larger canyon or valley. These circulations in turn may be modified by the larger lowlands-highlands circulation or, if near the coast, by the sea breeze. All of these can be affected in almost any degree by the gradient wind flow and such factors as the character of the topography, the vegetation, and the atmospheric stability. To study these interrelationships we need not only surface weather measurements but also measurements in the vertical, but we do not now have inexpensive ways of obtaining these measurements.

On each of the burns studied so far we determined that the weather pattern was the controlling factor affecting the fire behavior. The actual fire behavior was very close to that indicated by the wind pattern observed. Aside from the very local wind increase on the lee side of the fire in Burn 1-57, there were no other obvious effects of the fires on fireclimate patterns.

\section{REFERENCES}

1. Mark J. Schroeder and C. M. Countryman, "Fireweather Survey Can Aid Prescribed Burning," California Forest and Range Experiment Station, Technical Paper No. 21, 1957, 10 pp.

2. C. M. Countryman and M. J. Schroeder, "Preseribed Burn Fireclimate Survey 1-57," California Forest and Range Experiment Station, Technical Paper No. 29, 1958, 14 pp.

3. C. M. Countryman and M. J. Schroeder, "Prescribed Burn Fireclimate Survey 2-57," Pacific Southwest Forest and Range Experiment Station, Technical Paper No. 31, 1959, 18 pp.

4. C. M. Countryman and M. J. Schroeder, "Prescribed Burn Fireclimate Survey 3-57," Pacific Southwest Forest and Range Experiment Station, Technical Paper No. 34, 1959, 15 pp.

5. C. M. Countryman and M. J. Schroeder, "Preseribed Burn Fireclimate Survey 4-57," Pacific Southwest Forest and Range Experiment Station, Technical Paper No. 35, 1959, 19 pp.

6. U.S. Army, Engineer Research and Development Laboratories, Mass Fire Control Test, Report 1531-TR, 1958, 61 pp.

7. Howard F. Graham, "Fire Whirlwinds," Bulletin of the American Meteorological Society, vol. 36, No. 3, Mar. 1955, pp. 99-103. 